\title{
IMPACTS OF INTERNATIONAL MIGRATION ON SOCIO- ECONOMIC DEVELOPMENT IN BANGLADESH
}

\author{
MD. MASUD SARKER ${ }^{1}$ \\ MD. SHAHIDUL ISLAM ${ }^{2}$ \\ ${ }^{1}$ Department of Political Studies, Shahjalal University of Science and Technology, Bangladesh \\ ${ }^{2}$ Research and Development (R\&D) Cell, Bangladesh Knitwear Manufacturers and Exporters Association \\ (BKMEA), Dhaka, Bangladesh Institute of Social Research (BISR) Trust Bangladesh'
}

(C) 2018 Md. Masud Sarker, Md. Shahidul Islam

This is an open access article distributed under the Creative Commons Attribution-NonCommercial-NoDerivs license

(http://creativecommons.org/licenses/by-nc-nd/3.0/)

DOI: 10.1515/eras-2018-0003

\begin{abstract}
International migration has positive impacts on socio-economic development in Bangladesh. Using secondary data, this paper explores the impacts of remittances on socio-economic development in Bangladesh. The article reveals that remittance has significant impacts on Bangladesh economy and socio-economic development, for example, reducing the poverty, increasing the household expenditure, saving, leading to maintain the quality of life as well as gender equality. Therefore, the government should take necessary steps to fostering international migration as a national strategy for economic development of Bangladesh.
\end{abstract}

Keywords: Remittance, International Migration, Development, Economy, Bangladesh

\section{INTRODUCTION}

It is projected that more than 200 million people in the world are as of now living in the country which is not their home country and this number is rapidly increasing. Most of the time people migrate from developing countries to developed countries. It is generally estimated that half of the immigrants of developed countries are migrated from developing countries (Zhunio, 2012). The migrants people who send money to their families or friends in their country of origin are generally called remittance. Over the last 30 years, remittance flow to developing countries has gradually been increased, which accounts for 100 billion dollar on average per year. After the mid-1980, there is a rapid increase of migrations and global flow of remittance also increased sharply from $\$ 18$ billion in 1980 to $\$ 440$ billion by 2010 (Chowdhury et al. 2011). It is also assumed that a huge part of the remittance flow is unrecorded that may be 20 to $200 \%$ of the recorded remittance (Chowdhury, 2011). It is also estimated that in 2010, more than $80 \%$ global migrants worker are from developing countries, and they sent about $75 \%$ of the remittance to developing countries of the total remittance. The workers remittance is considered the lion share of foreign earnings for the most of the developing countries after foreign direct investment (Chowdhury, 2011). Remittance is also considering a stable source of money during the financial crisis (Ratha, 2007).

Migration has turned into a significant livelihood strategy for the people of Bangladesh, considering its comprehensive socio-economic development through transferring of skills, and community development. International migration is not a new phenomenon for Bangladesh. During the British period; people were migrated for UK and USA for business and educational purposes. But the flow of migration has been increasing in Middle East countries since 1970, due to increasing oil expiation in this countries and increasing the demand labour force (Islam, 2010). Bangladesh is one of the top ten remittance recipient countries in the world (Hatemi-j \& Uddin, 2014). In Bangladesh, international migration is the major driver of the economic 
development because it diffuses the knowledge, technology, idea and skill. Remittance is also the source capital for startup new small scale - SMEs and entrepreneurship (Hatemi-j \& Uddin, 2014).

Currently, in Bangladesh, the total population is being estimated to 158.5 million, where labour force participation rate of the population aged 15 or older at 58.5 percent, at 81.9 percent male and 35.6 percent for females and 41.5 percent of the population aged 15 or older outside the labour force. However, 2.6 million people aged 15 or older are still remaining unemployed (BBS, 2017). Most of them are uneducated and have very low skills that are not suitabe for the local job market. The wages paid for this jobs is very low that it can not support to lead their daily livelyhood. Most of the educated persons can not enter the job market after completion of their education because they have no experiences and skills related to jobs. This man-power can be an added value while they migrate to abroad as worker and make themselve as an asset not only for family and but for the country as well.

Therefore international migration which leads to flow the remittance can be an important startegy for national development for Bangladesh. This paper tries to expolre the imortance of remittane on development of Bangladesh and also explain the the effects of remittance on socio-economic development of Bangladesh.

\section{REMITTANCE FLOWS IN BANGLADESH}

\begin{tabular}{|l|l|l|l|}
\hline FY & $\begin{array}{l}\text { No } \\
\text { Employment }\end{array}$ & $\begin{array}{l}\text { of } \\
\text { Amount of remittance }\end{array}$ \\
\hline & Abroad 000 & In Million US\$ & $\begin{array}{l}\text { Percentage } \\
\text { Change \% }\end{array}$ \\
\hline $2007-08$ & 981 & 7914.78 & 32.39 \\
\hline $2008-09$ & 650 & 9689.16 & 22.42 \\
\hline $2009-10$ & 427 & 10987.40 & 13.40 \\
\hline $2010-11$ & 439 & 11650.32 & 6.03 \\
\hline $2011-12$ & 691 & 12843.40 & 10.24 \\
\hline $2012-13$ & 441 & 14461.15 & 12.60 \\
\hline $2013-14$ & 409 & 14228.30 & -1.61 \\
\hline $2014-15$ & 461 & 15316.91 & 7.65 \\
\hline $2015-16$ & 685 & 14931.14 & -2.52 \\
\hline $2016-17$ & 905 & 12769.5 & -14.48 \\
\hline
\end{tabular}

Table - 1: Remittance flows in Bangladesh

Source: Bangladesh Economic Review

In FY 2007-08, about 981 lakh workers were employed at abroad, but the trend was decreasing in FY 2010 -11, which was account for 439 lakh. But, FY 2011-12, the amount of workers employment at abroad risen to 691 lakh. However, recently, the migrant's worker estimated 905 lakh, which was higher than the previous year, which was an account for 685 lakh.

In 2007-08 period, the remittance earned was only USD 7914.781 million, after that, the trend was gradually increased up to FY2014-15 period, which account for US 15316.91 
million, the highest remittance earned. Recently the table reveals that US dollar 12769.5 in million remittances have been earned in 2015-2016 by the county which is lower than the previous year (US 14931.14) million in 2016-17).

\begin{tabular}{|c|c|}
\hline Year/Month & Growth (\%) \\
\hline 2017-2018 & -15.72315174 \\
\hline 2016-2017 & -14.47795821 \\
\hline $2015-2016$ & -2.518327783 \\
\hline 2014-2015 & 7.651322087 \\
\hline 2013-2014 & -1.610384797 \\
\hline $2012-2013$ & 12.59562282 \\
\hline 2011-2012 & 10.24100626 \\
\hline $2010-2011$ & 6.033456505 \\
\hline 2009-2010 & 13.39772078 \\
\hline $2008-2009$ & 22.41982721 \\
\hline $2007-2008$ & 31.94664639 \\
\hline 2006-2007 & 24.90541207 \\
\hline $2005-2006$ & 24.79334977 \\
\hline 2004-2005 & 14.12586707 \\
\hline 2003-2004 & 10.12420109 \\
\hline $2002-2003$ & 22.42346459 \\
\hline $2001-2002$ & 32.8903884 \\
\hline $2000-2001$ & -3.448382 \\
\hline 1999-2000 & 14.28001923 \\
\hline 1998-1999 & 11.82027363 \\
\hline 1997-1998 & 3.389543316 \\
\hline 1996-1997 & 21.22820568 \\
\hline 1995-1996 & 1.622370849 \\
\hline 1994-1995 & 10.00349034 \\
\hline 1993-1994 & 15.26091237 \\
\hline 1992-1993 & 11.17035049 \\
\hline 1991-1992 & 11.22514432 \\
\hline 1990-1991 & \\
\hline
\end{tabular}

Table 2. Growth rate of remittance

Source: Bangladesh bank 


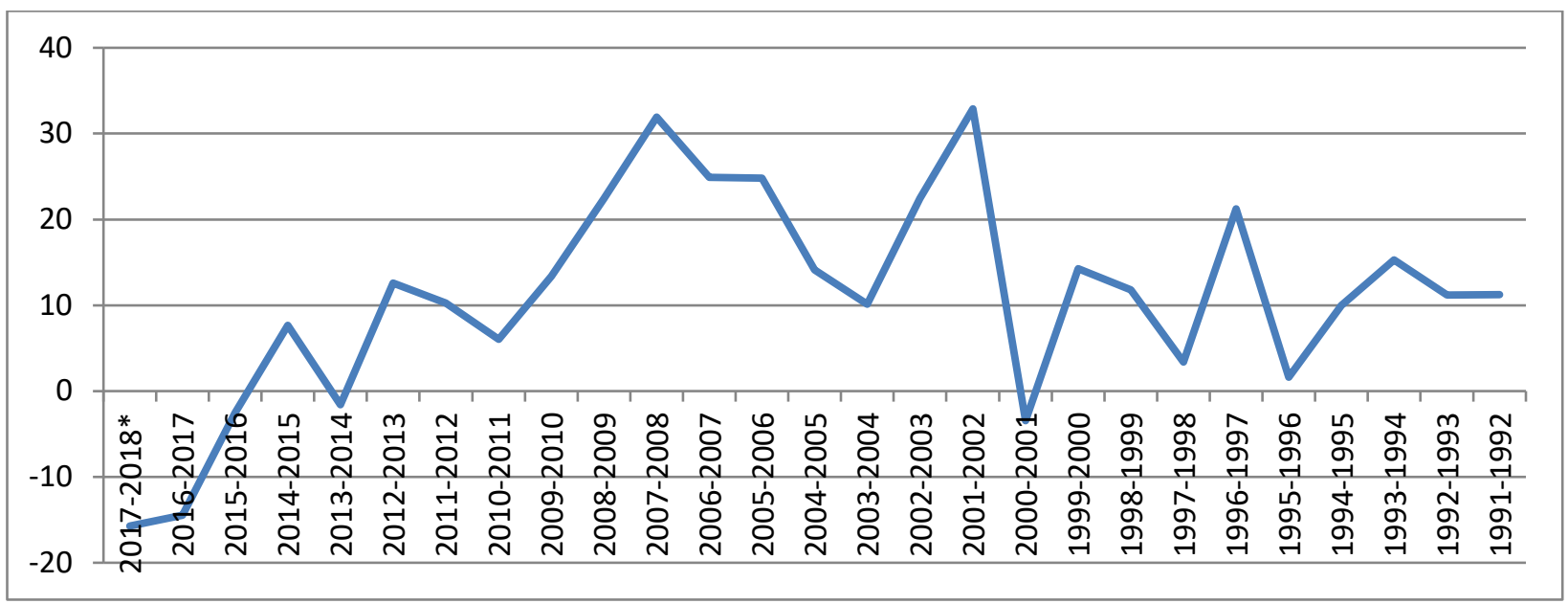

Figure -1: Trend of the growth rate of remittance

From Table 2, the remittance growth rate fluctuates from time to time. Growth rate saw positive trend from FY 1991-1992 periods to FY1999-2000 period, but it was downward in FY 2000-2001 period. After that, it was the stabilized trend up to FY 2012-2013. Recently, from FY 2015-2016 to FY2017-2018, the growth rate of remittance reduces dramatically.

\begin{tabular}{|l|l|l|l|l|l|l|l|l|l|}
\hline $\begin{array}{c}\text { Calendar } \\
\text { year }\end{array}$ & $\begin{array}{c}\text { Saudi } \\
\text { Arabia }\end{array}$ & Qatar & UAE & Bahrain & Oman & Malaysia & Singapore & other & Total \\
\hline 2010 & 7069 & 12085 & 203308 & 21824 & 42641 & 919 & 39053 & 63803 & 390702 \\
\hline 2011 & 15039 & 13111 & 282739 & 13996 & 135265 & 742 & 48667 & 58503 & 568062 \\
\hline 2012 & 21232 & 28801 & 215452 & 21777 & 170326 & 804 & 58657 & 90749 & 607798 \\
\hline 2013 & 12654 & 57584 & 13699 & 12275 & 62612 & 3203 & 30775 & 101681 & 409253 \\
\hline 2014 & 10657 & 87575 & 24232 & 23378 & 105748 & 5134 & 54570 & 114210 & 425684 \\
\hline 2015 & 58270 & 123965 & 25271 & 20720 & 129859 & 30483 & 55523 & 111790 & 555881 \\
\hline 2016 & 143913 & 120382 & 8131 & 72167 & 188247 & 40126 & 54730 & 130035 & 757731 \\
\hline 2017 & 302456 & 51826 & 2179 & 16460 & 50556 & 14846 & 19779 & 55527 & 513629 \\
\hline
\end{tabular}

Table - 3: Number of Expatriate Bangladeshi Workers by Country

Source: Bangladesh economic review, 2017

Nowadays, Bangladesh has been increasingly an important source country in international flows of labor migration since 1980s. Migration had started towards different industrialized countries including UK, USA, etc. alongside with to the Middle East and SouthEast Asian countries like Singapore, Kuwait, Malaysia, Bahrain, Abu Dhabi, etc. Till June, 2017 it has been estimated that almost 513629 people had been migrated to different countries especially to Saudi Arabia (302456), Qatar (51826), Bahrain (16460), UAE (2179), Oman (50556) Malaysia (14846), Singapore (19779) and others (55527). But among them, almost $80 \%$ percent of the people were worked in different countries of Middle East. 


\begin{tabular}{|l|c|c|c|c|c|c|c|c|c|c|c|c|}
\hline FY & KSA & UAE & USA & Kuawait & UK & QATAR & Oman & Singapore & Bahrain & Malaysia & Others & Total \\
\hline $\begin{array}{l}2012- \\
13\end{array}$ & 3829.5 & 2829.4 & 1859.8 & 1186.9 & 991.6 & 286.9 & 610.1 & 498.8 & 361.7 & 997.4 & 1009.1 & 14461.1 \\
\hline $\begin{array}{l}2013- \\
14\end{array}$ & 3118.9 & 2684.9 & 2323.3 & 1106.9 & 901.3 & 257.5 & 701.1 & 429.1 & 459.4 & 1064.7 & 1181.3 & 14228.3 \\
\hline $\begin{array}{l}2014- \\
15\end{array}$ & 3345.2 & 2823.8 & 2380.2 & 1077.8 & 812.3 & 310.2 & 915.3 & 443.4 & 554.3 & 1381.5 & 1263.9 & 15316.91 \\
\hline $\begin{array}{l}2015- \\
16^{*}\end{array}$ & 2955.55 & 2711.74 & 2424.32 & 1039.95 & 863.28 & 435.61 & 909.65 & 387.24 & 489.99 & 1337.14 & 1376.67 & 14931.14 \\
\hline $\begin{array}{l}2016- \\
17^{* *}\end{array}$ & 2267.2 & 2093.5 & 1688.9 & 1033.3 & 808.2 & 576.0 & 897.7 & 300.9 & 437.1 & 1103.6 & 1563.1 & 12769.5 \\
\hline
\end{tabular}

\section{Table - 4: Country wise remittance (In million US\$)}

Source: Bangladesh economic review, 2017

Majority of the remittance comes from KSA, but the data reveals that recently there is a rapid declined of remittance has been observed in KSA. Remittance flows reduced from FY 38295.5 to FY2012-2013 to 2267.2 in FY 2016-17. On the other hand, the remittance from the USA increased dramatically from US\$ 1859.8 in FY 2012-2013 to 2424.32 in FY2015-16 1859.8. Finally, in FY 2016-17 periods total remittance is estimated US\$12769.5 which was less than previous year, which accounts for US\$14931.14.

\begin{tabular}{|l|l|l|l|l|l|l|l|l|l|l|}
\hline FY & $\begin{array}{l}\mathbf{2 0 0 7 -} \\
\mathbf{0 8}\end{array}$ & $\begin{array}{l}\mathbf{2 0 0 8} \\
\mathbf{0 9}\end{array}$ & $\begin{array}{l}\mathbf{2 0 0 9 -} \\
\mathbf{1 0}\end{array}$ & $\begin{array}{l}\mathbf{2 0 1 0}- \\
\mathbf{1 1}\end{array}$ & $\begin{array}{l}\mathbf{2 0 1 1 -} \\
\mathbf{1 2}\end{array}$ & $\begin{array}{l}\mathbf{2 0 1 2}- \\
\mathbf{1 3}\end{array}$ & $\begin{array}{l}\mathbf{2 0 1 3}- \\
\mathbf{1 4}\end{array}$ & $\begin{array}{l}\mathbf{2 0 1 4} \\
\mathbf{1 5}\end{array}$ & $\begin{array}{l}\mathbf{2 0 1 5 -} \\
\mathbf{1 6}\end{array}$ & $\begin{array}{l}\mathbf{2 0 1 6}- \\
\mathbf{1 7}\end{array}$ \\
\hline $\begin{array}{l}\text { As percent of } \\
\text { GDP }\end{array}$ & 8.64 & 9.44 & 9.52 & 9.05 & 9.63 & 9.64 & 8.21 & 7.87 & 6.74 & 5.17 \\
\hline $\begin{array}{l}\text { As percent of } \\
\text { Export } \\
\text { Earnings }\end{array}$ & 56.09 & 62.25 & 63.48 & 50.82 & 52.92 & 53.52 & 47.78 & 49.08 & 43.61 & 49.22 \\
\hline
\end{tabular}

\section{Table - 5: Remittance as Percent of GDP and Export Earnings}

Source: Bangladesh Economic Review, 2017

In FY 2007-08, the percentage share of remittance to GDP was estimated 8.64 and percent of export earning which were 56.09. But from, FY 2007-08 to FY 2016-17, the percentage of GDP decreased to 5.17. Similarly, percentage of total export earnings from remittance declined in 49.22 in FY 2016-207.

\begin{tabular}{|l|l|l|}
\hline Year & total & Yearly increase \\
\hline 2005 & 13570 & 20.53 \\
\hline 2006 & 18045 & 32.98 \\
\hline 2007 & 19094 & 5.81 \\
\hline 2008 & 20842 & 9.15 \\
\hline 2009 & 22224 & 6.83 \\
\hline 2010 & 27706 & 24.67 \\
\hline
\end{tabular}




\begin{tabular}{|l|l|l|}
\hline 2011 & 30579 & 10.37 \\
\hline 2012 & 37304 & 21.99 \\
\hline 2013 & 56400 & 51.19 \\
\hline 2014 & 76007 & 34.76 \\
\hline 2015 & 103718 & 36.48 \\
\hline 2016 & 118088 & 13.85 \\
\hline 2017 & 121925 & 3.25 \\
\hline
\end{tabular}

Table - 6: Female employment from 2005 to December, 2017

Source: Bangladesh Economic Review, 2017

For the stable economic growth, both male and female have the same responsibility, international female migration has a significant effect on the developmental process of Bangladesh. Various different macro and micro level factors are the main determinates to female migration. In local job market, unskilled worker are paid low wage and have to engage venerable work. So they migrants to aboard for better income opportunity and wages, earning facility in the countries of destination, and for a better living standard. There is a rapid increase of female migration has been observed from 2005 to 2017. In 2015 female migrant was 13570 which are increased to 121925 in 2017 . During the last three years, as a substance amount of female migrants is observed.

\section{IMPACTS OF REMITTANCE ON SOCIO-ECONOMIC DEVELOPMENT}

\subsection{Remittance and poverty}

The impact of remittance on poverty reduction is huge which include firstly, migration is regarded as a vital driver for the advancement of economy and economic development through the diffusion of thoughts, skills, innovation and expertise. Secondly, migration and remittance create a relationship of mutual dependence between sending and receiving countries. Thirdly, remittance facilitates to establish small scale enterprises at local level thus helping to community development. Remittances also increase the flow of working capital for entrepreneurship development which creating the new job opportunity. (Woodruff and Zenteno, 2001). Most importantly, if the poorer section in the society is given opportunity to have access remittances through migration, the income inequality and poverty will be minimized and finally poverty will be diminished from the society. It is evident from practical situation of the households having remittances and without remittances.

Having considered the current situation, the workers remittance has been proved as the major determinant factor of socio-economic development of the Bangladesh (Farid et al. 2009). Remittance has direct and indirect impacts on poverty reduction in Bangladesh. The World Bank report shows that remittance contributed in reducing $6 \%$ of poverty in Bangladesh. Hatemi-j \& Uddin (2014) reveals that the remittance has a long run effects on poverty reduction in Bangladesh, and poverty and remittance reinforce each other. Remittance can play an important role to reduce the credit constraints (Taylor, 1999). Remittances can indirectly effect on poverty reduction when the money is being used for productivity, health and education at household. Evidences support that there is a strong association between remittance and GDP in Bangladesh (Akter, 2016: Paul \& Das (2011). BBS (2013) shows the remittances are becoming, if not only, the major sources of income among the 78 percent of remittance 
receiving households.

\subsection{Remittance and trade:}

Although remittance has positive impacts on socio-economic development of this country, it may have negative effects on trade and business in receiving country. But Chowdhury \& Rabbi( 2014) shows that remittance have the adverse effect of on trade competitiveness of Bangladesh because workers remittance is widely used for non-tradable sector as livelihoods and better quality of life, but not used for tradable sector (Chowdhury \& Rabbi, 2014).

\subsection{Remittance and saving:}

Remittance increases the household saving in Bangladesh. BBS (2015) reported that $40.71 \%$ remittance receiving household can save part of the remittance in 2015.Similarly, Haider et al. (2016) reveals that migration has increase the saving of the household, which accounts for increases 0.311 units saving.

\subsection{Remittance and quality of life:}

Remittance has great impact the quality of life on people in Bangladesh, because it increases the income, education and life expectancy. Based on data for HDI and remittance earning from 1981 to 2011, they concluded that the remittance has a significant effects on the improvement of quality of life in Bangladesh (Pradhan \& Khan, 2015)

\subsection{Remittance and education:}

Evidence supports that international remittance increase the household investigate in human capital in developing countries (Adams \& Cuecuecha, 2010). Remittance has direct and indirect effect on educational outcomes. Remittance money is invested for family and relatives' educational purpose like inputs like us educational institutions fees and materials. Remittance money can increase the budget for educational expenses compared to previous budget.

\subsection{Remittance and household expenditure:}

At the household level, remittance is used to fulfil their daily basic need, medical and other expenses. It also uses to buy assets, land, home car, and furniture and luxury goods.

\subsection{Remittance and gender:}

International migration has effects on the families; sometimes it affects the power stricter of the family. International migration can have effects on women position at household at three dimensions. Firstly, women who are migrated to abroad as a worker, are sent remittance to their family, have enjoyed the economic decision-making power at the household compared to when they are not migrated. Secondly, women whose husband is international labor migrants, directly receive the remittance from husband leads to change their position at left behind 
household. After the absent of husband, women take the responsibility, control over household authority and working as a household head of the family. They have control the household resources that enable them to enjoy higher autonomy, independence, freedom of movement, and decision making power. So, women who are receiving remittance from their husband are increasing the women empowerment not only at household but also at their community. Thirdly, But the scenery is different among the women who directly do not receive the remittance, they are becoming power less at their husband's family. When remittance receiver are family member of father in laws, women have no control over this money, treated as a passive member of the family, even not to allow to talk outside of the family member (Sarker \& Islam,2014).

5. Conclusion: Like other South-Asian countries, presently, Bangladesh is one of the topmost labour sending countries of the world. Labour migration, an important means of globalization, is the most significant path for socio-economic development of the country. For this reason, Bangladesh should take necessary steps to produce skill man-power through proper training. It is a crying need for Bangladesh to ensure appropriate training for its migrant labours before sending them abroad so as to make them able to earn handsome amount, and thus send an increased amount of remittance to home.

\section{REFERENCES}

Adams Jr, R. H., \& Cuecuecha, A. (2010). Remittances, household expenditure and investment in Guatemala. World Development, 38(11), 1626-1641.

Akter, S. (2016). Remittance Inflows and Its Contribution to the Economic Growth of Bangladesh.[Online]Availablefrom:http://dspace.lib.niigatau.ac.jp/dspace/bitstream/10191/41800/1/62_ 215-245.pdf

Bangladesh bureau of statistics (BBS), (2016). Report of The Survey on Investment from Remittance 2016

Bangladesh Bureau of Statistics (BBS) (2017).Bangladesh labor force survey.

Bangladesh Economic Review, 2017

Chowdhury, M. B. (2011). Remittances flow and financial development in Bangladesh. Economic Modelling, 28(6), 2600-2608.

Chowdhury, M. B., \& Rabbi, F. (2014). Workers' remittances and Dutch disease in Bangladesh. The Journal of International Trade \& Economic Development, 23(4), 455-475.

Farid, K. S., Mozumdar, L., Kabir, M. S., \& Hossain, K. B. (2009). Trends in international migration and remittance flows: Case of Bangladesh. Journal of the Bangladesh Agricultural University, 7(2), 387-394.

Haider, M. Z., Hossain, T., \& Siddiqui, O. I. (2016). Impact of remittance on consumption and savings behaviour in rural areas of Bangladesh. Journal of Business, 1(4), 25-34.

Islam, M. N. (2010). Migration from Bangladesh and Overseas Employment Policy. Dhaka: Bureau of Manpower, Employment and Training, Bangladesh. [Online] Available from: http://www.bmet.org. bd/BMET/resources/Static\% 20PDF\% 20and\% 20DOC/publication/Migration-BOEP. Pdf [Accessed: 10th March 2015].

Hatemi-J, A., \& Uddin, G. S. (2014). On the causal nexus of remittances and poverty reduction in Bangladesh. Applied Economics, 46(4), 374-382.

Paul, B. P., \& Das, A. (2011). The Remittance-GDP Relationship in the Liberalized Regime of Bangladesh: Cointegration and Innovation Accounting. Theoretical \& Applied Economics, 18(9).

Pradhan, M. A., \& Khan, G. U. (2015). Role of Remittance for improving quality of life: Evidence from Bangladesh. Turkish Economic Review, 2(3), 160.

Sarker, M., \& Islam, M. S. (2014). Husbands' international labour migration and the change of wives' position among the left-behind in rural Bangladesh. ISSN (Paper), 2224-5766.

Siddique, A., Selvanathan, E. A., \& Selvanathan, S. (2012). Remittances and economic growth: empirical evidence from Bangladesh, India and Sri Lanka. Journal of development studies, 48(8), 1045-1062. 
Taylor, J. E. (1999) The new economics of labour migration and the role of remittances in the migration process, International Migration, 37, 63-89

Zhunio, M. C., Vishwasrao, S., \& Chiang, E. P. (2012). The influence of remittances on education and health outcomes: a cross country study. Applied Economics, 44(35), 4605-4616. 